\title{
DEVELOPMENT OPPORTUNITIES OF HOMESTEADS IN RURAL AREAS A SOCIAL OR AN ECONOMIC QUESTION?
}

\author{
Dóra Nagyné Demeter* , Gábor Koncz \\ Eszterházy Károly University, Institute of Rural Development and Landscape management, Hungary
}

The survival of special Hungarian settlement forms (homesteads), due to the increasing urbanization phenomena, raises more and more questions. Are these forms of settlements of special, natural, landscape and cultural value? Or are the empty spaces that have lost their original function, which are relocating to the growing urban agglomerations? In our research, we sought to find out what kind of vision the Hungarian 'farm' could have on the $21^{\text {st }}$ century Hungarian Great Plain. On the one hand, our empirical research focused on a homestead survey in the BácsKiskun County, where we surveyed the general condition of the farms, and on the other hand we carried out an opinion survey of the population. We have tried to compare the opinion of the urban population and the vision of the people living on the farms, to identify new functions that will fit in with the European rural development policy, financial and professional support in the future. Our results show that diversified developments can help the survival and development of homesteads.

Keywords: rural settlements, suburbanisation, sustainability, rural lifestyle, functional transformation of rural areas, diversified local development

\section{Introduction}

The depopulation of rural areas has been a phenomenon throughout Europe for decades (Commins, 1978). The emigration of young people basically endangers the sustainable development of these spaces, so many ideas have been formulated to stop or reverse unfavourable demographic processes (Vidivkiené, 2017). Part of the development focuses on keeping the population in place, but in many cases accelerated depopulation is already a solution to immigration and the introduction of completely new features. In the suburbanisation phase of urban development, the more spacious, calmer rural areas are also at the forefront, but the rural areas often become attractive to those who have lived their entire life in a big city (Mieszkowski and Mills, 1993). However, the survival of depopulated rural settlements is often unimaginable without urban immigrants, but it can also lead to a significant transformation of the local way of life (Biolek et al., 2017). The encounter of a globally uniform urban value system and unique traditions can have specific economic and social consequences. The homestead is a unique characteristic of the Hungarian landscape in Europe. Farms can be considered as a special type of isolated settlement in terms of their formation and function, which, in the last centuries, have fundamentally defined the typical landscape of the Great Plain (extending $100,000 \mathrm{~km}^{2}$, of which $52,000 \mathrm{~km}^{2}$ in Hungary). The special and highly valuable farm system, its farmland spirit with its social and economic geographic, architectural, linguistic, ethnographic and landscape features and values is not only a part of Hungarian identity and national heritage, but also of European heritage. An important value of homesteads is that they are potentially suitable for implementing a sustainable development, integrated, complex rural development and multifunctional agriculture development model in Europe (NDTC, 2014). The homesteads adapt to our natural geographic features, the generations living here pass on our generation-breeding traditions from generation to generation, the knowledge gained and accumulated in farming, preserve our landscape varieties and our indigenous animal species, thus the richness of biodiversity, contribute to the sustainable use of the Hungarian landscape and the maintenance of the heterogeneous production culture (0GYH, 2009). In recognition of all these values, the homesteads were declared Hungaricum (a unique Hungarian phenomenon) in 2017.

The rural areas can be defined as socio-ecological systems, where the population and natural resources are linked (Schouten et al., 2009). Lower population density implies lower environmental impacts. Major environmental pressures and the health problems of the rural population are linked to industrialized agriculture (Robson and Schneider, 2001). Agroenvironmental programs were launched in a safe country to solve these problems (Barbu and Căpuşneanu, 2012). However, in sparsely populated areas, in most cases, clean air, a greener environment and a calmer, healthier and slower lifestyle are the real benefits of the rural environment. In addition, past research has also shown that moral duty and environmental behaviour levels are higher in rural environments than in urban environments (Berenguer et al., 2005).

In Hungary, the first stage of farm development roughly finished by the end of the $16-18^{\text {th }}$ century, when it came to take the place of the field gardens and the farms have replaced field farms. These homestead settlements were established between the Danube-Tisza River south of the Cegléd-Kiskunlacháza line, Jászság, and the Tiszántúl region bounded by the Maros-Pécska-Battonya-Gyula-Földes-Debrecen-Karcag-KunmadarasTisza line. Their development was induced by the intensive and economically uninhabitable settlement boundaries, intensive farming (arable farming, later grape and fruit growing), and the necessity and the abandonment of the possibilities for final relocation (establishment of villages on the more distant frontiers and wilderness). These factors have also determined the function of homesteads for a long time (Beluszky, 2004). The flourishing world of the early $20^{\text {th }}$ century was one of the cornerstones of the Great Plain's developing society. At that time, $40-50 \%$ of the total population lived on farms belonging to rural towns. Later, when the socialist agricultural model was being developed, this settlement model, which lived closely with the city, ceased to exist. Then, in the area of economic-social change, the previous ban on farm building was lifted (Csatári and Farkas, 2018). With this, the revival 
of the farms became possible, but only partially. With the strengthening of suburbanisation, new farm centres could have opened up new economic centres with the development of primarily farmed land and the development of profitable farm holdings (Becsei, 1992). Typically, however, these functional changes were only partially realized by the $21^{\text {st }}$ century.

While at the turn of the millennium, three main farmsteads were basically separated by the researchers (Table 1) according to the survey results, in 2005, non-agricultural use had already appeared. However, this was not predictable, because the farms' infrastructural supply was very low. Unfortunately, some of the agricultural farmlands are still confined to forced production. These are now becoming strange to the world and are being destroyed and phased out in the future. Agricultural production accounts for only a minor part of the prospective areas of recovery, with recreational sites and suburbanisation scales being more likely to appear (Vasárus et al., 2018). Based on this, the homesteads that once used to be a lifestyle and a place of residence have lost their dominant role and are less and less bound by their special lifestyle. Nowadays, there are basically scattered settlements where traditional or modern farming is carried out in a lifestyle way, as tourist resting places, for recreational purposes, or for self-sufficiency and mostly due to the force or suburbanisation (Csatári and Farkas, 2018).

The emergence of the European Union rural development policy has greatly helped the survival and change of functions of homesteads. From 2004 onwards, the farms appeared as beneficiaries in some programmes, but without a comprehensive development program. In the agri-environmental management programmes, the ones targeting farms (Perger, 2017) appeared primarily.

A more serious aid policy appeared in the case of homesteads when the development of homesteads appeared as a regional complex rural development programme of the National Rural Strategy for the period 2012-2020. In 2011, a specifically outlined farm development programme was announced in connection with this to support these dormant forms. However, the program cannot handle the socio-economic and ecological and environmental problems that determine the future of the farms (Kovács and Dóka, 2018). Aging and emigration are common problems in homesteads.
Without eliminating these two major problems, the homestead world cannot be sustained in the long run. There is also a problem according to Balogh (2004) that due to the lack of political advocacy for people, the schools in farms have ceased to exist (as children go to a village or town, so they do not want to return to a less modern farm), motorization and crime are getting bigger, there are many aging farms, and buildings that are dilapidated or run down are not attractive to anyone.

One or more generations of farmsteads set up for agricultural production only exist in traces. The adverse effects of the change of regime, such as the large-scale reorganization of agriculture, social and economic shocks are less favourable to the conventional settlement structure. Nowadays, the outskirts have changed in many respects to the building stock, function, population, and commitment to agriculture. As opposed to these aspects, recreation is a new form and guarantees the continued survival of the farmland. However, there is no big boom in the countryside and rural and settlement development plans still have to contain the farms and homesteads (Nagy et al., 2016).

The size of the farmland has stagnated over the past decades, and the inhabitants living in it have changed and transformed very much. There are not enough jobs and agriculture around the homesteads is present as a forced solution. Based on these, the homesteads are not the subject of serious interest to the young generation (Gálné Horváth, 2014).

\section{Material and methods}

\section{Test sample area}

The farms involved in the study belong to the homestead world of the DanubeTisza Interstate. Typically, many farms have survived in this part of the Great Plain, and today they are home to thousands of people. After the turn of the millennium, farms have been transformed and nowadays a significant part of them is a renewable farm adapted to the changing circumstances of our time, but the traditional farm life is less likely to survive. The homestead settlement in Kaskantyú, which we visited, typically belong to the "traditional" and modernized, non-producing farms in the above survey categories.

Table 1 Types of projected and implemented homesteads at the turn of the millennium

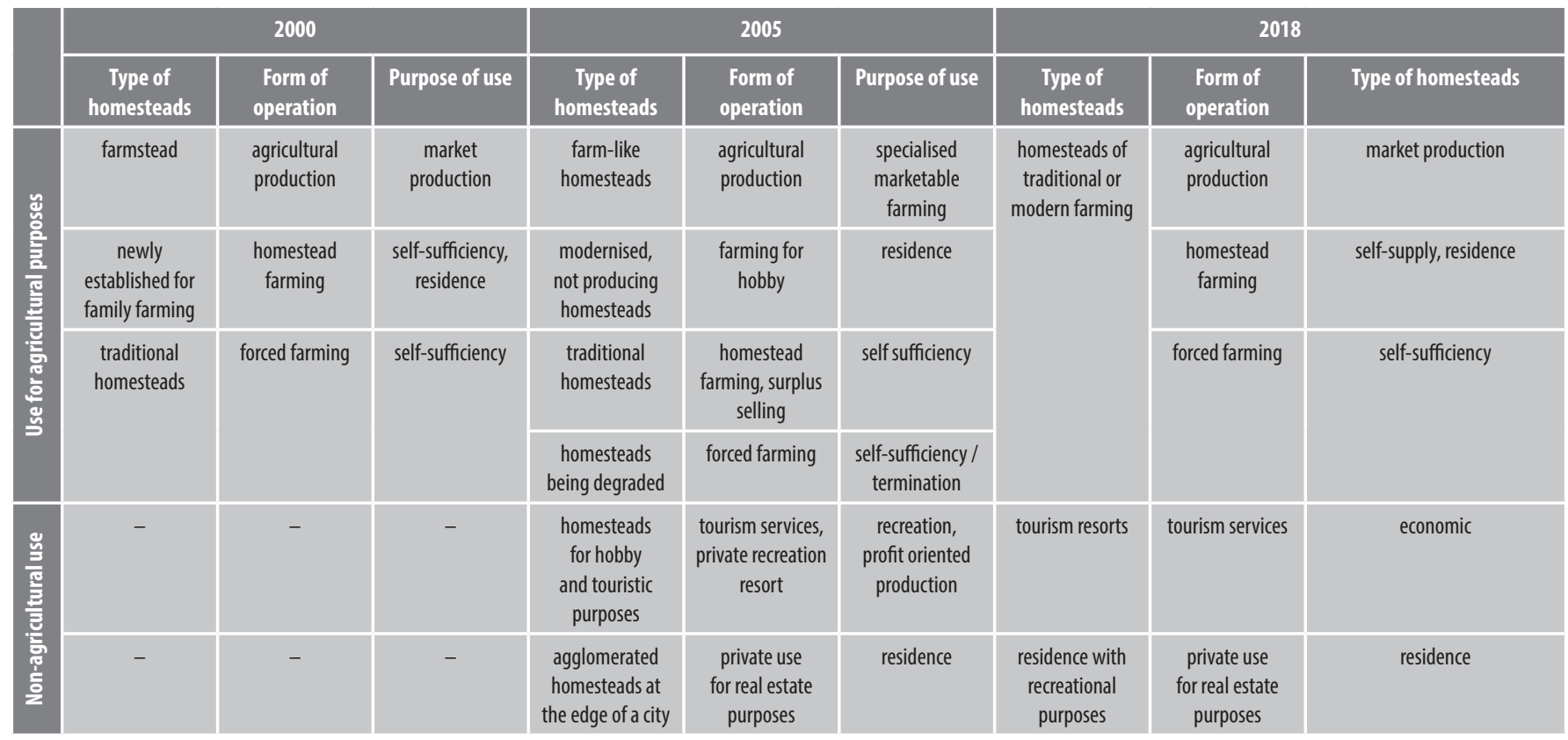

Source: author's own editing based on Becsei (2002), Csatári and Kanalas (2006), Petrás (2006a, 2006b), Csatári and Farkas (2018) 


\section{Hypothesis}

Several hypotheses were investigated during the research. The present study sought to find out whether the opinion of the inhabitants of the urban area is really negative about the farms, and, therefore, the social support of this settlement is low.

\section{Methods of data collection and analysis, characteristics of the test sample}

Our study is based on the results of two questionnaire surveys, in the framework of which we tried to assess the economic and social characteristics of the farms operating in our test area. With the help of the second questionnaire, we examined the opinion of the population living in urban areas of the country about the countryside.

In the framework of the first primary research, the questions were asked directly by questionnaires. The sample was made up of 75 inhabitants of the populated Kaskantyú farm, of which 26 families were able to get acquainted with their living conditions and opinions, representing $35 \%$ of the population, i.e. the survey is representative. The query was made personally for families. The purpose of this study was to find out the current situation of the Kaskantyú homesteads, both in housing and in economic terms.

In the second part of the study, we tried to reveal the opinion of the urban population about the farm world. The e-format self-completed questionnaire was filled in by 218 people. The examination began in spring 2017 and was closed in February 2018. The respondents were geographically concentrated in the counties of Bács-Kiskun and Pest, with nearly twothirds of the respondents residing in these counties. 59\% of the expatriates were urban and $41 \%$ were rural residents. Another feature of the sample is the over-representation of young people (53\% between 18 and 30 ) and graduates (49\%). The questions in the questionnaire focused on two main topics after recording the most important demographic data. The first group included the questions that we tried to grasp about the general image of people in the farms. The second set of questions included the issues of farm management, food production and the opportunities for selling food produce. The database was evaluated in Microsoft Excel 2016 and in context analysis (cross-table analysis) using IBM SPSS Statistics 20 programmes. In the study, the relationship between the variables was confirmed by the Pearson's Chi- square test, and the significance level of the Chi-square test was below 5\% accepted in science and social sciences. Continuing the cross-table analysis, we used the Cramer V. association coefficient to examine the strength of the relationship between the data.

\section{Results and discussion}

All 26 respondents in the farm are $100 \%$ satisfied with their farm life, so they are not forced to live here. They admit to the same degree that they are connected to the farm by the place of residence, family or that they were born there. Agricultural production does not appear in basic preferences. Based on the typing mentioned earlier, so far, the degrading farms are not included in our survey. The 26 surveyed farms can be classified into the types of traditional farm and modernized, non-producing farms. People living in the city were divided into two groups, depending on how well they know the farm life directly or indirectly. (A very high percentage of $81 \%$ of the respondents know a man living on a farm, the main reason being a large number of those from the Great Plain). In the form of an open question they could indicate what comes to their minds about life in the farm (Table 2).

At the same time, we also took into account the preferences of those living on the farm in their place of residence. The comparison shows that the nature-friendly, clean, calm environment is true for the farmsteads. However, the traditional $19^{\text {th }}$-century farmstead is still white-lined and wandering in the wilderness. A clean quality environment free of civilization damage is only known to those living on the farm. The mention of a quiet environment is likely to be in the forefront of disturbing urban noise every day. A projection of a kind of internal demand. The urban population is not bound to this type of settlement, although this function is a basic feature. Whether it is a residential property or a tourist resort, it is an essential property for farmsteads. Attitudes towards farms do not depend on how familiar the respondents are with this type of settlement. The mention of the residential function is only limited in the urban area. Considering that the examined farms are located only $5 \mathrm{~km}$ from their central settlement, Kaskantyú, we can conclude that a central settlement with urban functions is needed to develop an agglomerationtype farm with good infrastructure. Few mentioning can be explained by the opinion poll, which clearly revealed that the farm is still defined as a remote

Table 2 Associations of urban residents with farms and farm people preferences

\begin{tabular}{|c|c|c|c|}
\hline & Knows a person living in a homestead & Does not know a person living in a homestead & Homestead dwellers \\
\hline Great plain & + & + & - \\
\hline Tranquillity/calmness & +++ & + & +++ \\
\hline Residence & ++ & + & ++++ \\
\hline White building & + & - & - \\
\hline Farming & +++ & ++ & +++ \\
\hline All of the above & ++ & + & - \\
\hline Fresh air & - & - & +++ \\
\hline Being close to nature & - & - & +++ \\
\hline Agricultural activity & +++ & + & +++ \\
\hline Freedom, far from the modern world & - & - & ++ \\
\hline
\end{tabular}


location beyond the place of residence. During the survey, we asked our urban living respondents to estimate the distance between the farms and the nearest settlement. Most (47\%) believe the farm is 5-10 kilometres from the centre of the nearest settlement. After that, $40 \%$ say that this distance is $0-5$ kilometres. $13 \%$ say that a farm is more than 10 kilometres away. $69 \%$ of the farms in the examined area were located within 5 kilometres and only $31 \%$ were 5-10 kilometres. There was no farm that would be more than $10 \mathrm{~km}$ from the nearest settlement.

Similar tendencies are found in a 2016 survey carried out in the settlement area of Kecskemét, in which $60 \%$ of the respondents in the farm surveyed prefer to live in a farm and are very proud of their landscape and do not want to move out. Although these homesteads have a residential function, traditional family farms are also present. There are 7 of these 10 farms of the survey, which want to continue this important activity. An interesting lesson from this research was that it was initiated by leading intellectuals and top managers from the farmsteads who inherited their parents' farms, who are clearly aware of the value of the landscape and the potential applicability of modern rural development tools (Csatári et al., 2016). Associations should be compared with answers to a closed question. According to the majority of respondents, the main function of homesteads is to live and farm (88\%), $53 \%$ of them live and keep animals, $13 \%$ only produce for self-sufficiency and $5 \%$ say the farm serves as a residence only. The main function of the homesteads for centuries, i.e. the production of food, and the production of raw materials for food has now largely disappeared. Although this homestead-like farming has been seen as the biggest breakout point of the farms at the turn of the millennium, this feature is currently less typical. Rather, dependence on the city can be found in surveys. The former farming lifestyle is now limited to partial self-sufficiency (not producing 31\%, for selfsufficiency $38 \%$, for sale $31 \%$ ). There are only eight farms for sale, but there are only four offspring in this case who want to continue farming. During the development of homesteads, it is worthwhile to keep in mind what vision the society has. In the case of a positive image, economic and service activities on farms can be welcomed. Residents of urbanized areas are hopeful about the future of farms, as more than half of respondents (57\%) said that farms will have a future. According to $39 \%$, farms will play an important role in future farming, 29\% will stay in their current position, 17\% will disappear and $7 \%$ say they will move to the farms. $8 \%$ of respondents were unable to answer. In the future, therefore, farming will continue to be expected from homesteads.

However, the residential function is not currently present (Figure 1). As a reason for rejection responses, people in the village identified loneliness and underdevelopment, city dwellers, the distance between a city that provides a comfortable life, loneliness and "much work to do there." All of the listed are excellently presented together. The metropolitan and urban people would not choose the farm as their place of residence because of all these features. The future of homesteads, regardless of age or type of residence, was equally positively evaluated. According to all forms of settlement, farms will have a future. Half of the metropolitan respondents said yes, and half said no. According to the village and the town's inhabitants, farms will have a great future (Figure 2-3). The opinion of those aged $18-30$ and $31-50$ is almost the same on the role of farms. Most say farmsteads will play an important role in future farming and fewer that they will stay in their current position. The lower specific responses of the over 50 age group in each response category were due to the fact that they were basically smaller in the sample. The future functions of farms can be diverse, and it can be said that society is still expecting traditional farming activities. That is, they think in the traditional urban-rural context (the countryside supplies the city with food). However,

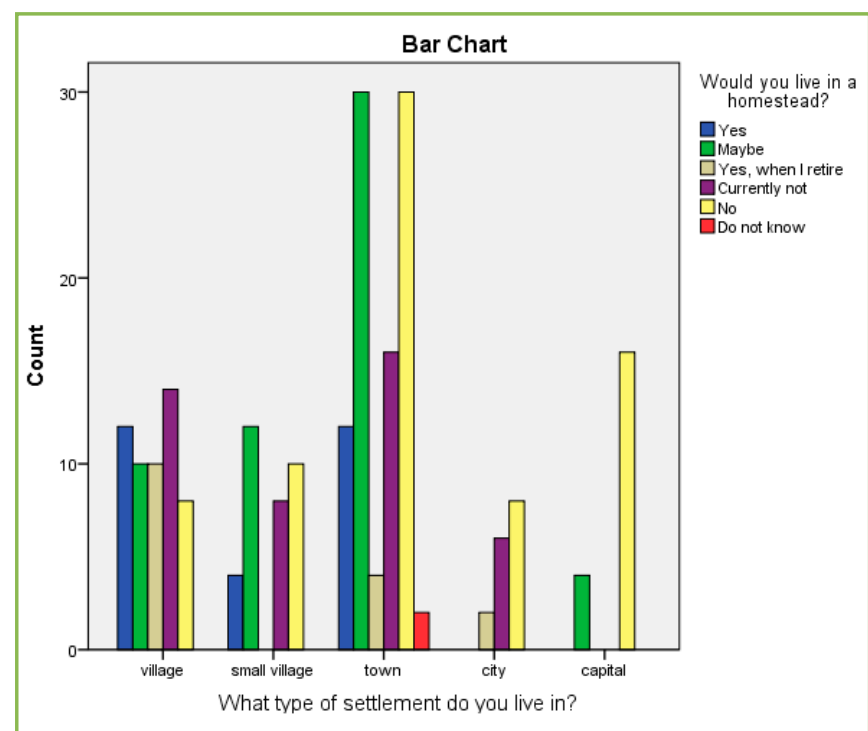

Figure 1 Assessment of the farm as a future residence based on the settlement category of current residence Source: author's own editing $n=218, p=0.00$

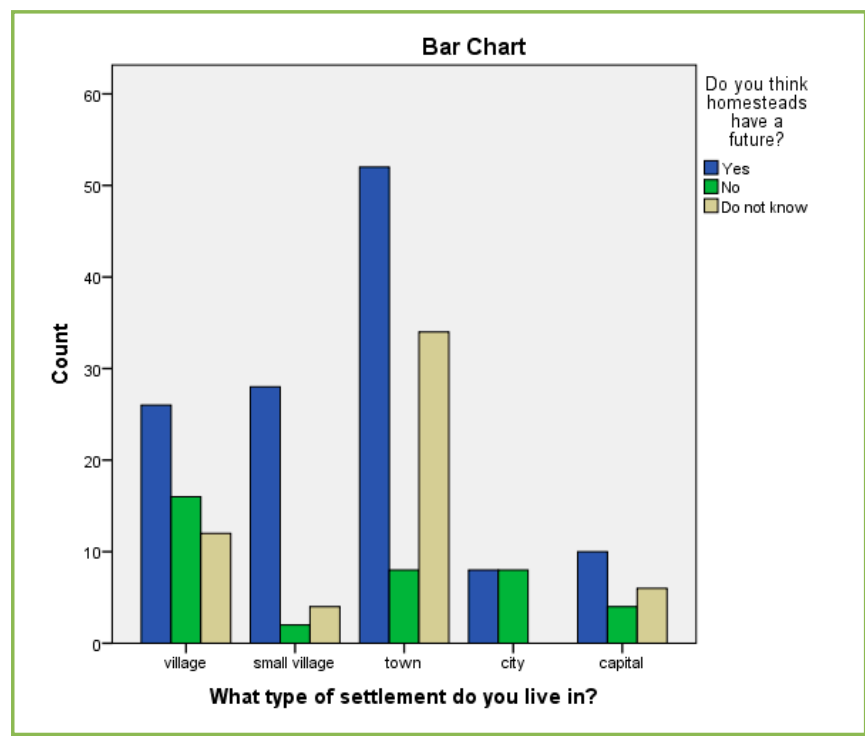

Figure 2 Assessment of the future of the farm as a settlement form based on the settlement category of current residence Source: author's own editing $n=218, p=0.00$

this does not work now and is expected to take a special form (e.g. new types of short supply chains) with significant support.

The social demand for the survival and operation of the homesteads is clearly present, regardless of the form of settlement. The associations with the word farm are sometimes romantic, bucolic, but overall positive. They display values that are actually present. This can provide an excellent basis for community-supported agricultural activities. The high-quality natural environment (free from civilization damage), the utilization of which can be a serious potential, should be given high priority, considering that the farms examined are not far from the more developed settlements. 


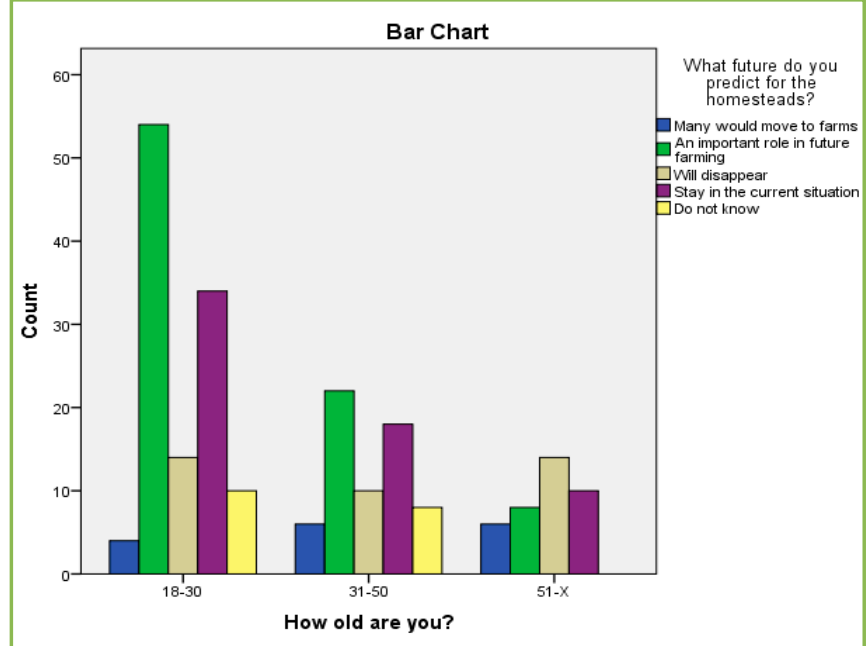

Figure 3 Possible vision of the farm world based on the age of the respondents Source: author's own editing $n=218, p=0.01$

\section{Conclusion}

The responses showed that farmland production plays an important role in future farming, as they are suitable for producing clean, healthy foods. However, the fact to what extent the agri-ecological features in certain regions limit agricultural production should be considered. It is more likely that the homesteads are able to dynamize high environmental quality as targets for recreation. To do this, the basic infrastructure is available, the development and continuous improvement of services will be more challenging. As the region basically shows an aging structure, which is even more typical of those living on the homestead, a lack of skilled labour can be a serious barrier to tourism development.

All in all, however, we can say that the farmsteads are not questionable in the $21^{\text {st }}$ century. Our basic hypothesis was rejected in the examination, and the opinion of people living in the urban area is essentially positive about the homesteads, and the social support of this settlement form is high.

\section{Acknowledgement}

This study was supported by EFOP-3.6.1-16-2016-00001“Kutatási kapacitások és szolgáltatások komplex fejlesztése az Eszterházy Károly Egyetemen“.

\section{References}

BALOGH, L. 2004. Bács-Kiskun megye tanyás térségeinek múltja jelene és jövője (The past and future of the homestead areas of Bács-Kiskun County). In (satári, B. - Kiss, A. (szerk.). Tanyai Kaleidoszkóp (Csatári, B. - Kiss, A. (ed.). Homestead kaleidoscope): Kecskemét : MTA RKK Alföldi Tudományos Intézete, 2004, pp. 144-146.

BARBU, C-M. - CĂPUŞNEANU, S. 2012. Agriculture, Environment and Sustainable Development of Rural Areas. In International Journal of Academic Research in Business and Social Sciences, vol. 2, 2012, no. 9, pp. 242-253.

BECSEl, J. 1992. Az alföldi tanyarendszer változásai és várható fejlődése (Changes and expected development of homestead system in the Great Plain). (Kutatási jelentés). (Research paper) OTKA 4511/1992, Budapest, 1992.

BECSEl, J. 2002. A tanyarendszer jövőbeni alakulására ható tényezők (Factors affecting the future development of the homestead system). In Magyar Tudomány (Hungarian Science), 2002, no. 9, pp. 1196-1213.

BELUSZKY, P. 2004. Magyarország településföldrajza (Geography of settlement in Hungary). Budapest : Dialóg Campus Kiadó, 2004, 568 p.
BERENGUER, J. - CORRALIZA, J.A. - MARTíN, R. 2005. Rural-Urban Differences in Environmental Concern, Attitudes, and Actions. In European Journal of Psychological Assessment, vol. 21, 2005, no. 2, pp. 128-138.

BIOLEK, J. - ANDRÁŠKO, I. -MALÝ, J. - ZRŮSTOVÁ, P. 2017. Interrelated aspects of residential suburbanization and collective quality of life: A case study in Czech suburbs. In Acta Geografica Slovenica, vol. 57, 2017, no. 1, pp. 65-75.

COMMINS, P. 1978. Socio-economic adjustments to rural depopulation. In Regional Studies, vol. 12, 1978, no. 1, pp. 79-94.

CSATÁRI, B. - FARKAS, J. Zs. 2018. Az alföldi tanyák változó szerepe a településszerkezetben (The role of the Great Plain farms in the settlement structure). In A Falu (The village), vol. 33, 2018, no. 3, pp. 33-48.

CSATÁRI, B. - FARKAS, J.ZS.-KOVÁCS, A.D. 2016. Egy alföldi tanyás mezőváros terének dinamikus változásai Kecskemét példáján (Dynamic changes in the territory of a homestead in the Great Plain, following the example of Kecskemét). In Kókai, S. (szerk.). A változó világ XXI. századi kihívásai (The XXI. century challenges of changing world), University of Nyíregyháza Institute of Tourism and Geography, 2016, pp. 89-109.

CSATÁRI, B. - KANALAS, I. 2006. A homokhátsági tanyák jelene és területi jellemzőik (The present and territorical character of homestead in Homokhátság). In A Falu (The village), vol. 21, 2006, no. 2, pp. 95-105.

GÁLNÉ HORVÁTH, I. 2014. A Hódmezővásárhely környéki tanyák és tanyaközpontok vizsgálata a tér és idő összefüggésében (Studying of homestead and homestead centers aroun Hódmezôvásárhely in context of space and time) (PhD dissertation). University of Pécs Faculty of Sciences Doctoral School of Earth Sciences, 2014, 197 p.

KOVÁCS, A.D - DÓKA, R. 2018. Tanyák a tájban - gondolatok a tanyás térségek környezeti összefüggéseiről (Farmsteads in the Landscape - Philosophic on the Environmental context of homestead areas). In A Falu (The Village), vol. 33, 2018, no. 3, pp. 61-72.

MIESZKOWSKI, P. - S. MILLS, E. 1993. The Causes of Metropolitan Suburbanization. In Journal of Economic Perspectives, vol. 7, 1993, no. 3, pp. 35-147.

NAGY, G. - DUDÁS, G. - BODNÁR, G. 2016. Megfogyva bár... Egy tanyafelmérés tanulságai Békés megyében (Diminishing, although... Lessons from a survey of the outskirts in Békés county). In Tér és Társadalom (Space and Society), vol. 30, 2016, no. 1, pp. 93-111.

NEMZETI FEJLESZTÉS. 2030 - Országos Fejlesztési és Területfejlesztési Koncepció (National Development and Territorial Development Concept of Hungary (NDTC)). 2014. Parliament Resolution No. 1/2014. (I. 3.) OGY.

PERGER, É. 2017. Az Országos Fejlesztési és Területfejlesztési Koncepcióban szereplő térségkategóriák felülvizsgálatának megalapozása (The foundation of the review of the regional categories included in the National Development and Regional Development Concept). Kutatási jelentések (Research report). On behalf of the Ministry of National Economy, Institute For Regional Studies, Centre For Economic And Regional Studies, Hungarian Academy Of Sciences, Kecskemét, 2017.

PETRÁS, E. 2006a. Fönntartható-e a tanyai településforma? Családi gazdaságok a kiskunhalasi tanyavilágban (Is the homestead as settlementform sustainable? Family farms in homesteadland of Kiskunhalas). Kutatási jelentés (Research report). http://geography.hu/mfk2006/pdf/Petr\%E1s\%20Ede.pdf

PETRÁS, E. 2006b. A homokhátsági tanyák jellemzői az adatlapok alapján (Characteristics of homesteads in Homokhátság based on data sheets). Research report, 2006, 69p.

RESOLUTION 49/2009. (V. 27.) of the National Assembly on the preservation and development of homesteads and farm areas (OGYH).

ROBSON, M. - SCHNEIDER, D. 2001. Environmental health issues in rural communities. In Journal of environmental health, vol. 63, 2001, no. 10, pp. 16-19.

SCHOUTEN, M. - van der HEIDE, M. - HEIJMAN, W. 2009. Resilience of social-ecological systems in European rural areas: theory and prospects. In Paper prepared for presentation at the $113^{\text {th }}$ EAAE Seminar "The Role of Knowledge, Innovation and Human Capital in Multifunctional Agriculture And Territorial Rural Development", Belgrade, Republic of Serbia, December 9-11,2009. 18 p.

VASÁRUS, G. - BAJMÓCY, P. - LENNERT, J. 2018. In the shadow of the city: demographic processes and emerging conflicts in the rural-urban fringe of the Hungarian agglomerations. In Geographica Pannonica, vol. 22, 2018, no. 1, pp. 14-29.

VIDICKIENÉ, D. 2017. Attractiveness of Rural Areas for Young, Educated Women in PostIndustrial Society. In Eastern European Countryside, vol. 23, 2017, no. 1, pp. 171-190.

\section{Contact address}

Dóra Nagyné Demeter (PhD), Eszterházy Károly University, Institute of Rural Development and Landscape management 3200 Gyöngyös Mátrai str. 36. e-mail: ndemeter.dora@uni-eszterhazy.hu 